\title{
Plasma renin activity in acute poststreptococcal glomerulonephritis and the haemolytic-uraemic syndrome
}

\author{
H. R. POWELL, * E. ROTENBERG, A. L. WILlIAMS, and D. A. McCREDIE \\ From the Department of Paediatrics, University of Melbourne, and the Royal Children's Hospital, Melbourne, \\ Australia
}

\begin{abstract}
Powell, H. R., Rotenberg, E., Williams, A. L., and McCredie, D. A. (1974). Archives of Disease in Childhood, 49, 802. Plasma renin activity in acute poststreptococcal glomerulonephritis and the haemolytic-uraemic syndrome. Plasma renin activity (PRA) was determined in 10 children with acute glomerulonephritis and in 10 with the haemolytic-uraemic syndrome (HUS). Low renin levels were found in the hypertensive children with acute nephritis, all of whom had evidence of fluid overload. The amount of this overload correlated directly with the degree of hypertension and inversely with PRA. All the hypertensive children with HUS had high levels of plasma renin, and the highest levels were found in those cases who were subsequently shown to have the more severe degree of renal arteriolar occlusion. The findings emphasize the importance of measures designed to reduce salt and water overloading in the management of hypertension in acute nephritis, while drugs which suppress plasma renin are more likely to control blood pressure in HUS. Estimation of PRA may provide a guide to the management of hypertension in acute renal insufficiency.
\end{abstract}

Hypertension commonly occurs during the course of acute renal failure. Its cause has been attributed both to increased cardiac output from salt and water overload (DeFazio et al., 1959) and to increased peripheral vascular resistance due to release of renin with consequent formation of angiotensin (Warren and Ferris, 1970; Kokot and Kuska, 1969). Previous studies have shown a rise in PRA in man and animals with acute renal failure associated with tubular injury caused by ischaemia ( $\mathrm{Tu}, 1965$; Brown et al., 1970) or toxins (Brown et al., 1972). The cause and significance of this raised PRA is not yet established. Arakawa et al. (1970) have suggested that renin may be released from injured renal tissue in a manner similar to the release of enzymes from other injured tissues, e.g. transaminases from liver or muscle. However, as tubular necrosis is not always present in acute renal failure with a high PRA, a local pathogenetic role for renin in the development of oliguric renal failure has been suggested (Brown et al., 1970).

\footnotetext{
Received 25 March 1974.

^Present address: Department of Child Health, University of Birmingham.
}

We have examined the PRA levels during the early stages of acute renal failure in children suffering from acute poststreptococcal glomerulonephritis or from idiopathic HUS. In both these conditions salt and water overload is commonly seen, while in HUS arteriolar changes also occur and lead to glomerular ischaemia (Habib et al., 1969). A study of changes in PRA in these disorders might therefore be expected to help elucidate the pathogenesis of the hypertension which often complicates their course.

\section{Patients and methods}

Ten previously well children, aged 6 months to 8 years, with HUS were studied. All had a mild gastroenteritislike illness in the week before admission and presented with an acute microangiopathic haemolytic anaemia (haemoglobin 3.6-6.6 $\mathrm{g} / 100 \mathrm{ml}$ ), thrombocytopenia (platelet count $1000-70,000 / \mathrm{mm}^{3}$ ), and acute renal failure with blood urea levels of 72-524 mg/100 ml (Table I). None was dehydrated and most were slightly oedematous. 5 had a diastolic blood pressure $>90$ $\mathrm{mmHg}$ on repeated measurements and these all required antihypertensive drugs. In the other 5 children diastolic 
TABLE I

Features about the time of presentation in children with haemolytic-uraemic syndrome

\begin{tabular}{|c|c|c|c|c|c|c|}
\hline Case no. & $\begin{array}{c}\text { Age } \\
\text { (mth) }\end{array}$ & $\begin{array}{c}\mathbf{H b} \\
(\mathrm{g} / 100 \mathrm{ml})\end{array}$ & $\begin{array}{l}\text { Platelets } \\
\text { (per } \mathbf{m m}^{3} \text { ) }\end{array}$ & $\begin{array}{l}\text { Blood urea } \\
(\mathrm{mg} / 100 \mathrm{ml})\end{array}$ & $\begin{array}{c}\text { Pretreatment blood } \\
\text { pressure } \\
(\mathbf{m m H})\end{array}$ & $\begin{array}{c}\text { PRA } \\
(\mathbf{n g} / \mathbf{m l} \text { per } \mathbf{h r})\end{array}$ \\
\hline $\begin{array}{l}1 \\
2 \\
3 \\
4 \\
5\end{array}$ & $\begin{array}{r}13 \\
6 \\
101 \\
23 \\
24\end{array}$ & $\begin{array}{l}5 \cdot 5 \\
6 \cdot 2 \\
4 \cdot 6 \\
3 \cdot 9 \\
5 \cdot 0\end{array}$ & $\begin{array}{r}15,000 \\
4,000 \\
17,000 \\
12,000 \\
70,000\end{array}$ & $\begin{array}{l}156 \\
315 \\
220 \\
524 \\
460\end{array}$ & $\begin{array}{l}180 / 140 \\
130 / 100 \\
160 / 100 \\
140 / 100 \\
155 / 95\end{array}$ & $\begin{array}{r}10 \cdot 7 \\
32 \cdot 0 \\
7 \cdot 0 \\
6 \cdot 7 \\
7 \cdot 2\end{array}$ \\
\hline $\begin{array}{r}6 \\
7 \\
8 \\
9 \\
10\end{array}$ & $\begin{array}{r}15 \\
19 \\
11 \\
21 \\
8\end{array}$ & $\begin{array}{l}6 \cdot 2 \\
3 \cdot 6 \\
6 \cdot 2 \\
6 \cdot 0 \\
6 \cdot 6\end{array}$ & $\begin{array}{r}30,000 \\
30,000 \\
15,000 \\
33,000 \\
1,000\end{array}$ & $\begin{array}{r}243 \\
348 \\
179 \\
310 \\
72\end{array}$ & $\begin{array}{l}110 / 70 \\
110 / 70 \\
100 / 70 \\
120 / 65 \\
105 / 60\end{array}$ & $\begin{array}{l}7 \cdot 7^{\star} \\
1 \cdot 3 \\
1 \cdot 6 \\
0 \cdot 5 \\
0 \cdot 2\end{array}$ \\
\hline
\end{tabular}

^Case 6 had received intravenous frusemide 12 hours before blood for PRA was taken.

blood pressure was never greater than $80 \mathrm{mmHg}$. 6 were oligoanuric ( $<250 \mathrm{ml}$ urine $/ \mathrm{m}^{2}$ per day) for $6-35$ days, and these were all treated by peritoneal dialysis. Correction of clinical overhydration by dialysis did not restore blood pressure to normal in the patients who were also hypertensive.

All 10 children with HUS were treated with heparin, aspirin, and dipyridamole, and all but one (Case 10) were given streptokinase. 2 died after 22 and 35 days of oligoanuria, and histological examination of necropsy specimens was carried out. Renal biopsy was performed in 7 of the 8 survivors, in the second month after presentation, at a time when thrombocytopenia and hypertension had resolved. The severity of the pathological changes in the glomeruli and arterioles was graded by one of us (A.L.W.) without knowledge of the previous blood pressure or PRA levels. The severity of the glomerular changes was assessed semiquantitatively by noting the proportion of glomeruli in which all capillary lumina were occluded by fibrin thrombi and increased mesangial substance. The degree of occlusion of glomerular arterioles by fibrin-like material and/or intimal cell proliferation was assessed in each case according to the following scale.
Grade 0 -normal-the lumina of all arterioles were of normal calibre.

Grade +-partial occlusion-the lumina of some or all of the arterioles were reduced but none was completely obliterated.

Grade ++ -complete occlusion-the lumina of some or all of the arterioles were completely obliterated.

Ten children aged 4 to 12 years with acute glomerulonephritis were studied (Table II). All presented with acute onset of macroscopical haematuria, oligoanuria, and azotaemia, and 9 were hypertensive. Antistreptolysin 0 titres were raised at presentation in all but one (Case 14) in whom a Group A $\beta$-haemolytic streptococcus was isolated from a throat swab. Serum levels of the third component of complement $\left(\beta_{1} c / \beta_{1} A\right.$ globulin) were reduced in all. These patients were managed by salt and water restriction and all survived with normal blood pressure and blood urea at follow-up. Diuresis occurred regularly within 10 days of admission in the 9 hypertensive patients and during this time weight losses of $1 \cdot 1$ to $6.9 \mathrm{~kg}$ occurred, representing $6 \cdot 1$ to $14 \cdot 7 \%$ of the oedematous body weight. The normo-

TABLE II

Features at the time of presentation in children with acute nephritis

\begin{tabular}{|c|c|c|c|c|c|c|c|c|}
\hline \multirow{2}{*}{ Case no. } & \multirow{2}{*}{$\begin{array}{l}\text { Age } \\
\text { (yr) }\end{array}$} & \multirow{2}{*}{$\begin{array}{l}\text { ASO titres } \\
(I U / m l)\end{array}$} & \multirow{2}{*}{$\begin{array}{c}\beta_{1} \mathrm{c} / \beta_{1} \mathrm{~A} \\
(\mathrm{normal} \\
80-160 \mathrm{mg} / 100 \mathrm{ml})\end{array}$} & \multirow{2}{*}{$\begin{array}{l}\text { Blood urea } \\
(\mathrm{mg} / 100 \mathrm{ml})\end{array}$} & \multicolumn{2}{|c|}{ Weight loss during diuresis } & \multirow{2}{*}{$\begin{array}{l}\text { Pretreatment } \\
\text { blood pressure } \\
\text { (mmHg) }\end{array}$} & \multirow{2}{*}{$\begin{array}{c}\text { PRA } \\
\text { (ng/ml per hr) }\end{array}$} \\
\hline & & & & & (kg) & $(\%)$ & & \\
\hline $\begin{array}{l}11 \\
12 \\
13 \\
14 \\
15 \\
16 \\
17 \\
18 \\
19\end{array}$ & $\begin{array}{r}7 \\
11 \\
12 \\
12 \\
8 \\
12 \\
6 \\
8 \\
5\end{array}$ & $\begin{array}{l}480 \\
240 \\
480 \\
120 \\
240 \\
500 \\
240 \\
500 \\
500\end{array}$ & $\begin{array}{r}26 \\
28 \\
52 \\
41 \\
41 \\
<10 \\
<10 \\
46 \\
22\end{array}$ & $\begin{array}{r}170 \\
234 \\
47 \\
82 \\
58 \\
86 \\
126 \\
81 \\
109\end{array}$ & $\begin{array}{l}6 \cdot 9 \\
4 \cdot 0 \\
5 \cdot 4 \\
5 \cdot 8 \\
3 \cdot 4 \\
3 \cdot 6 \\
2 \cdot 3 \\
3 \cdot 1 \\
1 \cdot 1\end{array}$ & $\begin{array}{r}14 \cdot 7 \\
11 \cdot 7 \\
12 \cdot 1 \\
13 \cdot 2 \\
9 \cdot 8 \\
9 \cdot 2 \\
9 \cdot 0 \\
7 \cdot 9 \\
6 \cdot 1\end{array}$ & $\begin{array}{l}190 / 130 \\
170 / 125 \\
170 / 120 \\
170 / 115 \\
170 / 110 \\
170 / 110 \\
145 / 110 \\
180 / 110 \\
140 / 95\end{array}$ & $\begin{array}{l}0.06 \\
0.03 \\
0.27 \\
0.06 \\
0.07 \\
0.20 \\
0.40 \\
0.41 \\
0.15\end{array}$ \\
\hline 20 & 4 & 240 & $<10$ & 59 & $\mathbf{0}$ & $\mathbf{0}$ & $90 / 60$ & 0.67 \\
\hline
\end{tabular}


tensive patient (Case 20) was not oedematous and did not lose weight during recovery. Renal tissue was not obtained for histological examination in these children.

PRA was determined in terms of the amount of angiotensin I generated hourly on incubation of $1 \mathrm{ml}$ plasma at $37^{\circ} \mathrm{C}$ for 3 hours at natural $p H$ in the presence of inhibitors of angiotensinases and converting enzyme (2.6 mmol/1. EDTA, $1.6 \mathrm{mmol} / 1$. dimercaprol, and 3.4 $\mathrm{mmol} / \mathrm{l}$. 8-hydroxyquinoline). Angiotensin I was measured by radioimmunoassay as described by Haber $e t$ al. (1969). The blood was drawn into chilled heparinized tubes containing $1 \%$ of $0.3 \mathrm{~mol} / \mathrm{l} . \mathrm{Na}_{2}$ EDTA and plasma collected after centrifugation at 2000 r.p.m. at $2^{\circ} \mathrm{C}$. The plasma was stored at $-20^{\circ} \mathrm{C}$ until assayed within 2 weeks of collection. The normal range of PRA in our laboratory for children aged 9 months to 15 years on a salt-free diet is $0 \cdot 6-2 \cdot 3 \mathrm{ng} / \mathrm{ml}$ per hr when supine. Blood for PRA estimations was taken during the early phase of acute renal failure with the patient supine. Replicate determinations of PRA were done in many samples and the reproducibility of the results was $\pm 7 \%$. This is comparable with the $\pm 12 \%$ variation reported by Sealey, Gerten-Banes, and Laragh (1972). Sodium intakes were close to zero in all patients at the time of the blood sampling for PRA, and 3 hypertensive patients with HUS (Cases 1, 2, and 3) had started treatment with methyldopa. In several patients additional estimations of PRA were done later in the illness.

\section{Results}

HUS. 5 of the 10 cases of HUS had a diastolic blood pressure of $>90 \mathrm{mmHg}$. All of these had raised PRA in blood taken when they were hypertensive and in acute renal failure, values ranging from $6 \cdot 7$ to $32 \mathrm{ng} / \mathrm{ml}$ per $\mathrm{hr}$ (Table I). Fluid restriction and dialysis to correct oedema did not restore blood pressure to normal in any of these 5 children, all of whom subsequently required antihypertensive drug therapy. Methyldopa, a drug known to lower PRA (Mohammed et al., 1969), was used in all patients.

In 2 children (Cases 4 and 2) PRA was again estimated after the blood pressure had returned to normal and antihypertensive treatment ceased 9 and 19 days, respectively, after the initial estimations. Levels of 2.3 and $1.7 \mathrm{ng} / \mathrm{ml} \mathrm{per} \mathrm{hr}$, respectively, were found. Of the 5 normotensive children with HUS, 4 had levels of PRA which were normal or less than normal, ranging from 0.2 to $1.6 \mathrm{ng} / \mathrm{ml} \mathrm{per} \mathrm{hr}$, while one patient who had a raised level had been given intravenous frusemide 12 hours before the blood sample was taken.

The severity of subsequent histological changes is shown in Table III. The 2 children who died (Cases 3 and 9) had a much higher proportion of totally avascular glomeruli than the survivors. No relation was shown between the severity of the
TABLE III

Renal histology in children with HUS

\begin{tabular}{c|c|c|c}
\hline $\begin{array}{c}\text { Case } \\
\text { no. }\end{array}$ & $\begin{array}{c}\text { Total no. } \\
\text { glomeruli in } \\
\text { section }\end{array}$ & $\begin{array}{c}\text { No. glomeruli } \\
\text { with no patent } \\
\text { capillary lumina } \\
\text { (and \%) }\end{array}$ & $\begin{array}{c}\text { Arteriolar } \\
\text { luminal } \\
\text { occlusion }\end{array}$ \\
\hline 1 & 34 & $3(9)$ & ++ \\
2 & 33 & $0(0)$ & ++ \\
3 & $\begin{array}{c}\text { Necropsy } \\
\text { section }\end{array}$ & $(50)$ & + \\
4 & 20 & $0(0)$ & + \\
5 & 42 & $2(5)$ & + \\
6 & 17 & $0(0)$ & + \\
7 & 05 & $0(0)$ & + \\
8 & 58 & $0(0)$ & + \\
9 & Necropsy & $(100)$ & + \\
& section & & + \\
\hline
\end{tabular}

$\star 0$, normal lumina; + , partial occlusion; ++ , complete occlusion.

glomerular changes and PRA levels. Case 9, who at necropsy had total cortical necrosis with no patent glomerular capillaries, had a subnormal PRA and was never hypertensive.

Some degree of arteriolar occlusion was noted in all but Case 9 . Sections in 2 patients (Cases 2 and 1) showed complete occlusion of some arterioles and these patients had been previously found to have the highest PRA levels $(32.0$ and $10.7 \mathrm{ng} / \mathrm{ml}$ per $\mathrm{hr}$ ). Those with partial occlusion of arterioles had either raised (4 cases) or normal (2 cases) PRA.

Acute glomerulonephritis. During the period of oliguria PRA was low in the 9 hypertensive children with acute nephritis $(0.03$ to $0.41 \mathrm{ng} / \mathrm{ml}$ per hr) all of whom were oedematous. Patients with the greatest percentage weight loss on diuresis tended to have the lowest levels of PRA, and this inverse association between weight loss and PRA was significant at the $0.001<P<0.01$ level $(r=-0 \cdot 78)$. There was a highly significant correlation between diastolic blood pressure and subsequent weight loss $(r=0.96, P<0.001)$ (Fig. 1). This direct relation between the degree of salt and water overload and hypertension was noted in serial observations of each of these children. Fig. 2 illustrates the course of the illness in Case 19 who had a subnormal urine output until the seventh day in hospital. After this diuresis occurred and she lost $6.1 \%$ of her body weight with a simultaneous return of the blood pressure to normal. During the initial week of oliguria, oedema, and hypertension in this child three estimations of PRA (on days 2, 4, and 6) showed persistently low levels, but after diuresis on day 11 PRA had returned to normal. At this time blood pressure and urine output were normal and her weight had fallen to a stable level. The 


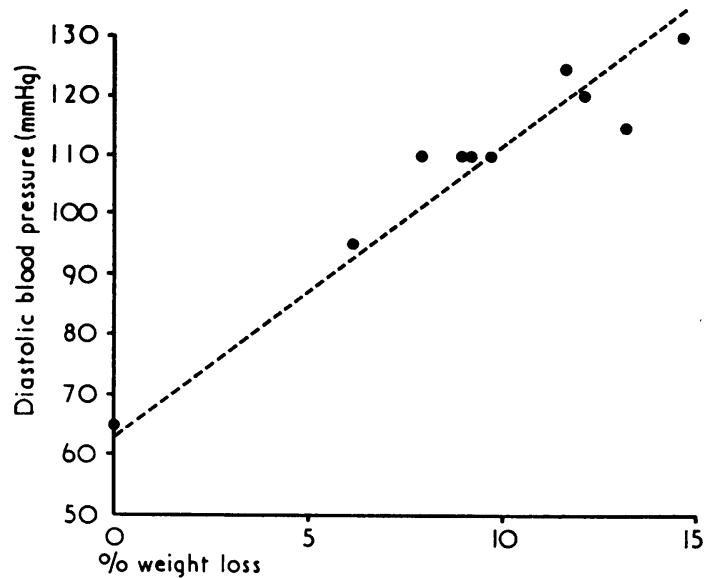

FIG. 1.-Relation between diastolic blood pressure and subsequent weight loss in 10 children with acute nephritis $(r=0.96)$. Regression equation: diastolic blood pressure $=4.9 \times \%$ weight loss +63 .

only normotensive patient with acute nephritis (Case 20) had a normal PRA when oliguric and was neither clinically oedematous nor lost weight during recovery.

\section{Discussion}

It is clearly established that factors which decrease the pressure of blood perfusing the kidneys result in release of renin from the juxtaglomerular cells of the afferent arterioles. Such factors include acute haemorrhage (McKenzie, Lee, and Cook, 1966), drug induced hypotension (Kaneko et al., 1967), assumption of the erect posture (Cohen, Conn, and Rovner, 1967), sodium depletion (De Champlain et al., 1966), and renal artery stenosis (Brown et al., 1965). Renin release is thought to result from the effect of reduced pressure on stretch receptors in the afferent arteriolar walls in the region of the juxtaglomerular apparatuses (Tobian, 1962). The less well-defined role of distal tubular sodium reabsorption in controlling renin release does not need to be considered to explain the PRA changes we have observed in HUS and acute nephritis.

In HUS the glomerular capillaries are occluded by a combination of thrombosis and mesangial matrix expansion (Habib et al., 1969), and these changes were seen in all 9 children in whom tissue was obtained for histological examination. Afferent arteriolar occlusion by intimal cell proliferation and fibrin-like material also occurred in most patients (Table III), and involved vessels proximal to their juxtaglomerular apparatuses. Such occlusion
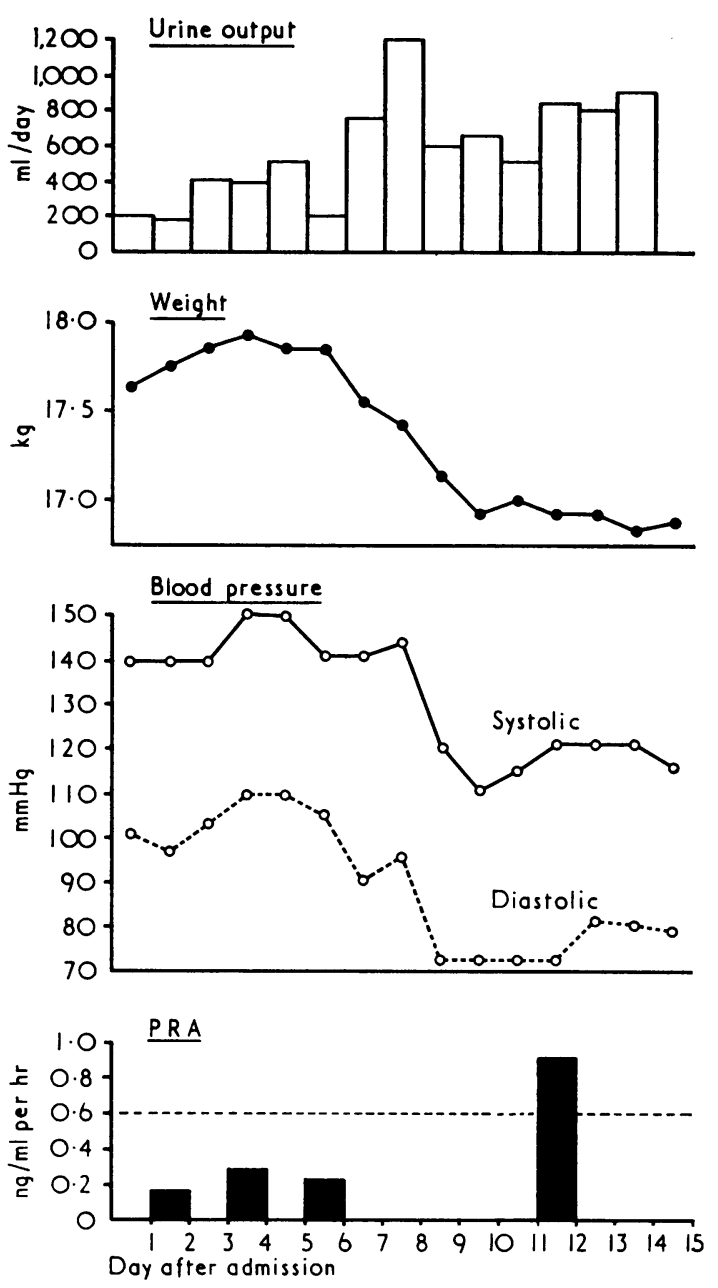

FIG. 2.-Serial observations of urine output, weight, blood pressure, and PRA in Case 19 with acute nephritis.

Broken line in PRA scale shows lower limit of normal.

would be expected to lead to reduction in stretch of the vessel walls more distally despite the raised arterial blood pressure, and hence to renin release. The results suggest that the more severe the arteriolar occlusion, the greater is the rise in PRA.

Renal tissue could not be obtained at the time of blood sampling for PRA estimation during the acute stages of the illness because thrombocytopenia and anticoagulant therapy are contraindications to closed renal biopsy. Biopsies were therefore performed in the second month after the onset of the disease, when hypertension and thrombocytopenia were no longer present and after stopping anti- 
coagulant therapy. As the evolution of the arteriolar lesions over the first two months is not well documented, it is not possible to draw definite conclusions from the association we have observed between the PRA and the severity of the arteriolar occlusions, though it seems logical to relate increased PRA to the degree of vascular obstruction. As some vessel changes were present in 3 cases who were never hypertensive, the lesions cannot be considered to be entirely secondary to hypertension.

Renal cortical necrosis is frequently seen at necropsy in cases of HUS (Habib et al., 1969) and was present in the 2 children who died. One of these (Case 9) had almost total cortical necrosis and all glomeruli were completely avascular. This patient, however, did not have a raised PRA and was never known to be hypertensive. This observation suggests that renin release in acute renal failure associated with tubular injury is not simply a consequence of cell necrosis, as Arakawa et al. (1970) have suggested occurs in renal infarction. It is, however, possible that tissue necrosis occurred a sufficiently long time before the blood sampling for the PRA to have fallen significantly.

In acute poststreptococcal glomerulonephritis the principal pathological change is in the glomeruli and there is an associated decrease in glomerular filtration rate and a lesser decrease in renal blood flow (Repetto et al., 1972; Farber, 1957). This suggests that reduction in renal blood flow is due to obstruction at the glomerular level, i.e. distal to the pressure sensing cells of the juxtaglomerular apparatus. Reduction in glomerular filtration rate leads to salt and water retention and expanded blood volume (DeFazio et al., 1959). Blood volume expansion may be expected to increase stretch in the vessel wall in the region of the juxtaglomerular apparatus and is known to suppress renin release (Newsome and Bartter, 1968). The low levels of PRA which we have consistently seen indicate that hypertension in acute nephritis cannot be attributed entirely to renin release. The significant correlation between degree of salt and water overload and rise in blood pressure suggests that this overload is the cause of the hypertension. This is supported by the serial observations in Case 19 in whom blood pressure and PRA reverted to normal with correction of the fluid overload and increase in urine output. It remains possible that PRA, though depressed in acute nephritis, is inappropriately high for the level of salt and water overload and therefore both factors could contribute to the hypertension in this disease (Birkenhäger et al., 1970). Similarly, oliguria leads to clinical salt and water overload in many cases of HUS. It seems likely that this might increase the effect of an already high plasma renin level in producing hypertension. 2 of the children with HUS had a subnormal PRA and were oedematous though not hypertensive.

Removal of salt and water by dialysis did not control the hypertension of HUS patients and all hypertensive cases required drug therapy. It has recently been suggested (Bühler et al., 1972) that PRA should be used as a guide in the choice of therapy in hypertension, a high level of PRA suggesting the use of $\beta$-adrenergic-blocking drugs. Propranolol, like methyldopa, has been shown to lower PRA (Bühler et al., 1972; Mohammed et al., 1969). Some of our hypertensive cases of HUS with high PRA were on methyldopa at the time of the blood sampling for PRA estimation and so even higher levels may have been found if samples had been taken before therapy. None of the patients with normal or low PRA levels was on antihypertensive drugs, though one normotensive patient with HUS had been given frusemide a few hours before the blood sampling and this may have induced the high PRA in this case (Fraser et al., 1965).

Our observations suggest that therapy with methyldopa or propranolol is likely to be more effective than the removal of salt and water by dialysis or diuretics in the high renin hypertension of HUS. In contrast, diuretics (Repetto et al., 1972) or dialysis seem to be the treatment of choice in the hyporeninaemic hypertension of acute nephritis. HUS and acute nephritis are the commonest causes of acute renal failure associated with hypertension seen in paediatrics and this study of the changes in renin activity in the plasma in these cases aids in the understanding of the pathogenesis of the hypertension and in the choice of antihypertensive therapy.

\section{REFERENCES}

Arakawa, K., Torii, S., Naito, S., Minohara, A., Uemura, N., and Nakamura, M. (1970). Plasma renin activity as a more specific diagnostic aid for renal infarction. Archives of Internal Medicine, 125, 830.

Birkenhäger, W. H., Schalekamp, M. A. D. H., SchalekampKuyken, M. P. A., Kolsters, G., and Krauss, X. H. (1970). Interrelations between arterial pressure, fluid volumes, and plasma-renin concentration in the course of acute glomerulonephritis. Lancet, 1, 1086.

Brown, J. J., Davies, D. L., Lever, A. F., and Robertson, J. I. S. (1965). Plasma renin concentration in human hypertension. II. Renin in relation to aetiology. British Medical fournal, 2, 1215.

Brown, J. J., Gleadle, R. I., Lawson, D. H., Lever, A. F., Linton, A. L., MacAdam, R. F., Prentice, E., Robertson, J. I. S., and Tree, M. (1970). Renin and acute renal failure: studies in man. British Medical fournal, 1, 253.

Brown, W. C. B., Brown, J. J., Gavras, H., Jackson, A., Lever, A. F., McGregor, J., MacAdam, R. F., and Robertson, J. I. S. (1972). Renin and acute circulatory renal failure in the rabbit. Circulation Research, 30, 114. 
Bühler, F. R., Laragh, J. H., Baer, L., Vaughan, E. D., and Brunner, H. R. (1972). Propranolol inhibition of renin secretion. A specific approach to diagnosis and treatment of renin-dependent hypertensive diseases. New England fournal of Medicine, 287, 1209.

Cohen, E. L., Conn, J. W., and Rovner, D. R. (1967). Postural augmentation of plasma renin activity and aldosterone excretion in normal people. Fournal of Clinical Investigation, 46, 418.

De Champlain, J., Genest, J., Veyratt, R., and Boucher, R. (1966). Factors controlling renin in man. Archives of Internal Medicine, 117, 355.

DeFazio, V., Christensen, R. C., Regan, T. J., Baer, L. J., Morita, Y., and Hellems, H. K. (1959). Circulatory changes in acute glomerulonephritis. Circulation, 20, 190.

Farber, S. J. (1957). Physiologic aspects of glomerulonephritis. Fournal of Chronic Diseases, $5,87$.

Fraser, R., James, V. H. T., Brown, J. J., Issac, P., Lever, A. F., and Robertson, J. I. S. (1965). Effect of angiotensin and of frusemide on plasma aldosterone, corticosterone, cortisol, and renin in man. Lancet, $2,989$.

Haber, E., Koerner, T., Page, L. B., Kliman, B., and Purnode, A. (1969). Application of a radioimmunoassay for angiotensin I to the physiologic measurements of plasma renin activity in normal human subjects. Fournal of Clinical Endocrinology and Metabolism, 29, 1349.

Habib, R, Courtecuisse, V., Leclerc, F, Mathieu, $\mathbf{H}$, and Royer, $\mathbf{P}$ (1969). Etude anatomo-pathologique de 35 observations de syndrome hémolytique et urémique de l'enfant. Archives Françaises de Pédiatrie, 26, 391.

Kaneko, Y., Ikeda, T., Takeda, T., and Ueda, H. (1967). Renin release during acute reduction of arterial pressure in normo- tensive subjects and patients with renovascular hypertension. fournal of Clinical Investigation, 46, 705.

Kokot, F., and Kuska, J. (1969). Plasma renin activity in acute renal insufficiency. Nephron, 6, 115.

McKenzie, J. K., Lee, M. R., and Cook, W. F. (1966). Effect of hemorrhage on arterial plasma renin activity in the rabbit. Circulation Research, 19, 269.

Mohammed, S., Fasola, A. F., Privitera, P. J., Lipicky, R. J., Martz, B. L., and Gafiney, T. E. (1969). Effect of methyldopa on plasma renin activity in man. Circulation Research, 25, 543.

Newsome, H. H., and Bartter, F. C. (1968). Plasma renin activity in relation to serum sodium concentration and body fluid balance. fournal of Clinical Endocrinology and Metabolism, 28, 1704.

Repetto, H. A., Lewy, J. E., Braudo, J. L., and Metcoff, J. (1972). The renal functional response to furosemide in children with acute glomerulonephritis. Fournal of Pediatrics, 80, 660 .

Sealey, J. E., Gerten-Banes, J., and Laragh, J. H. (1972). Renin system: variations in man measured by radioimmunoassay or bioassay. Kidney International, 1, 240.

Tobian, L. (1962). Relationship of juxtaglomerular apparatus to renin and angiotensin. Circulation, 25, 189.

Tu, W. H. (1965). Plasma renin activity in acute tubular necrosis and other renal diseases associated with hypertension. Circulation, 31; 686.

Warren, D.' J., and Ferris, T. F. (1970). Renin secretion in renal hypertension. Lancet, 1, 159.

Correspondence to Dr. D. A. McCredie, Royal Children's Hospital, Flemington Road, Parkville, Victoria 3052, Australia. 